\title{
Bionic Bodies, Posthuman Violence and the Disembodied Criminal Subject
}

\author{
Sabrina Gilani ${ }^{1} \mathbb{C}$ \\ Accepted: 6 November 2020 / Published online: 20 November 2020 \\ (c) The Author(s) 2020
}

\begin{abstract}
This article examines how the so-called disembodied criminal subject is given structure and form through the law of homicide and assault. By analysing how the body is materialised through the criminal law's enactment of death and injury, this article suggests that the biological positioning of these harms of violence as uncontroversial, natural, and universal conditions of being 'human' cannot fully appreciate what makes violence wrongful for us, as embodied entities. Absent a theory of the body, and a consideration of corporeality, the criminal law risks marginalising, or altogether eliding, experiences of violence that do not align with its paradigmatic vision of what bodies can and must do when suffering its effects. Here I consider how the bionic body disrupts the criminal law's understanding of human violence by being a body that is both organic and inorganic, and capable of experiencing and performing violence in unexpected ways. I propose that a criminal law that is more receptive to the changing, technologically mediated conditions of human existence would be one that takes the corporeal dimensions of violence more seriously and, as an extension of this, adopts an embodied, embedded, and relational understanding of human vulnerability to violence.
\end{abstract}

Keywords Bionic bodies $\cdot$ Corporeality $\cdot$ Criminal law theory $\cdot$ Embodiment $\cdot$ New materialism $\cdot$ Posthumanism

\section{Introduction}

A theory of the body is curiously absent from the criminal law on violence. It is remarkable that the law of homicide and assault, offences that are so intimately connected with bodily experience, never question the body in condemning violence and prohibiting its commission. In the way that these offences are structured, how they are adjudicated, we are given the impression that the body is a natural,

Sabrina Gilani

s.gilani@sussex.ac.uk

1 School of Law, University of Sussex, Brighton, Sussex BN1 9RH, UK 
pre-given, incontestable feature of human existence. That there is a realness to the body, a materiality that underpins all historical, socio-cultural interpretations of it, and which is independently and intimately implicated in the experience of violence. Whether bodies are recognised as Black or White, male or female, citizen or noncitizen, there is a realness to violence, we believe, that pre-exists the law. There are things violence can do to our bodies, does do to our bodies, which demand criminal legal intervention.

With this in mind the criminal law sets itself the task of limiting the body's exposure to violence and punishing it when it occurs (Ashworth and Horder 2013, p. 237). Operating on the assumption that there is an ahistorical, natural, passive material body - the biological body - the criminal law imputes to its experiences a shared morality (Ashworth and Horder 2013, p 35). On this basis, all humans, given our shared biological history, are believed to experience the physical effects of violence in the same way, are equally exposed to its risks and, for this reason, perceive (or should perceive) violence as morally wrongful. By fixing how the material body experiences violence, and by treating these experiences as universal and natural, it is the mind, the aspects of human experience that can be controlled, adjusted, 'corrected' that becomes the focal point of criminal legal intervention. The material body thus fades into the background. It becomes so common that we forget it is there.

In the first section of the paper, 'The Criminal Law's Materialisations of Death and Injury', I argue that a law of assault and homicide structured along these lines of thinking is misguided for two reasons. First, because it presumes the presence of a material, immutable and pre-given human body - a human body whose experiences and performances of violence can be universalised. I explain how the law of homicide and assault refers to this shared experience of violence as 'death' and 'injury'. The characterisation of death and injury as 'matters of fact', as natural, immutable, biological states that violated bodies undergo, is an understanding of death and injury that I dispute. Drawing on the work of corporeal feminists and neo-materialists, I show how death and injury are materialised or brought into being through the epistemological practices of the criminal legal process (Grosz 1994; Haraway 1991; Braidotti 2013; Barad 2007; Kirby 2018; Mol 2002; Coole and Frost 2010; Massumi 2002). ${ }^{1}$ The biological body is itself, I argue, mutable and mediated.

Second, I argue that the law of homicide and assault is misguided because it presumes, wrongly I might add, that the 'psychical interiority' that gives meaning to violence, that distinguishes acceptable from unacceptable experiences of it, operates independently 'of [any] corporeal exteriority' (Grosz 1994, p. xii). Criminal legal intervention is justified on the basis of harm; essentially, as I highlight above, when violence causes death or injury. While the dead and injured body might initially

\footnotetext{
1 This part of the analysis is heavily indebted to the work of new materialists such as Kirby, Coole and Frost, Haraway, Barad and Mol, all of whom develop and expand a new materialist methodology of diffractive analysis and a performative ethics that looks at the body as an onto-epistemological construct. From this perspective, bodies are materialised through our ways of studying, measuring, observing, writing about, providing images of, bodily phenomena (Barad 2003, 2007; Mol 2002; Haraway 1992).
} 
engage the criminal law of homicide and assault, it soon becomes the passive, inert, background conditions against which discussions about individual subjectivity and consent are foregrounded. In this paper I suggest that death and injury are not the passive, biological (and thus 'pre-legal') conditions we imagine them to be. The criminal law enacts the harms it associates with death and injury by interpreting silent, leaking, punctured, bruised, immobile bodies as evidence of the cessation of individual subjectivity and the absence of consent. We are given the impression that it is the state of being dead and injured that define the wrongfulness of violence for us. But is this true? Even Feinberg argues that, particularly when it comes to death, bodies are harmed long before they are pronounced 'dead' by the criminal law (Feinberg 1986, pp. 79-80); long before they are made to die by the discursive devices through which we interpret the violated body.

In this paper I argue that the criminal law needs a theory of the body because bodies - as material extensions of our 'selves' - are plastic and mutable. Not all bodies, not even all human bodies, are vulnerable to death and injury in the same way. The body's vulnerability to violence is not static and absolute, and this plasticity must be accounted for by the law of criminal violence. By treating concepts like 'consent' and 'subjectivity' as disembodied, as having the same meaning and material consequences for all human bodies, runs the risk of denying the full extent of violence's harmfulness to those with non-normative bodies.

To argue that harm, or the 'legitimate violation of someone's interests' (Ashworth and Horder 2013, p. 28), is unaffected by corporeality, or how bodies exist and operate in the world around them, is to lose sight of what violence means to us. It is to treat decisions that we make, and which may lead to its infliction, as if they are independent of the bodies that we occupy, the material constraints which are imposed on our very day-to-day existence-as raced, gendered, sexualised, mechanised bodies. In neglecting corporeality then, I believe, the criminal law is missing a crucial piece of the overall picture of what makes human beings vulnerable to violence.

In the second section of this article, 'Bionic Bodies and Posthuman Violence', I sketch out why the biotech revolution and the presence of bionic bodies makes these questions about the biological roots of death and injury a timely critique of the criminal law. For how can, and indeed how should, we expect the criminal law to regulate violence against human bodies that do not die, and injure in ways that we have come to accept as evidence of violence's wrongfulness? It is not difficult to imagine how bionic bodies, bodies that are both organic and inorganic, bodies that may not bleed or sense pain or stop working, or whose limbs are synthetic and replaceable, may pose problems for a criminal law of homicide and assault, that recognises the harms of violence through the interpretation of a very specific set of material and physical effects and impressions it leaves on bodies. I argue that the criminal law cannot precisely account for the harms of assault and homicide without taking into consideration the material constraints under which bodies operate (i.e. without taking stock of the fact that bodies with prosthetic limbs, bodies that can be 'revived' or brought back to life, live life differently). Human existence is a vulnerable existence. But this vulnerability is, as I will argue, embodied, embedded, and relational. It is not absolute and it is not universal. Human vulnerability cannot simply be traced to our biology, the body's physical limits: vulnerability is lived; it changes, it mutates 
depending on other bodies, ideas, and matter with which we come into contact. And if our vulnerability is precisely what the criminal law sets out to attend to, then it needs to adopt a posthuman notion of violence which, as a first crucial step, accepts human vulnerability as active, plastic, and dependent on ideas that constrain our becoming, and the relationships that we forge with that which lies beyond the contours of our own bodies. This paper thus advances the kind of 'affirmative ethics' that eminent neo-materialists such as Braidotti speaks of (2019), and connects the criminal law to wider discussions of the posthuman condition and questions of the Anthropos (Grear 2015).

\section{The Criminal Law's Materialisations of Death and Injury}

There has been much written about how the criminal law operates with the appearance of being ahistorical and natural; a 'rationalising enterprise' structured around a, purportedly, disembodied subject (Norrie 2014, pp. 10-13). Indeed, some legal theorists have even argued that in a modern liberal democracy, justice demands the assumption of an abstract, universal, rational, and autonomous legal subject (Hart 2009); a subject unencumbered by the ascription of social difference and the attribution of differential moral worth. Inclusivity and liberal justice, from this view, requires that we 'unsee' that which is fixed, the body which is 'real' and material (Rawls 2009, p. 3-18), and direct our energies to the social, the meaningful, the mutable. As many liberal humanists would argue, the material limits of the body, its physicality, its vulnerability to pain and death, is what unites us as a species (Phillips 2015), and for this reason a just and inclusive law would be one that takes these vulnerabilities of human existence as pre-given; as a sign of being 'human'. The focus of such a law would then become the 'mind' and its cognitive processes; those aspects of 'being human' that define us as individuals, as distinct from one another. The body simply becomes the background conditions of being human, and on which the law operates. Nevertheless, as many critical theorists have argued, the disembodied legal subject actually operates on the basis of a very particular bodied perspective. As feminist theorist Sarah Ahmed notes

the disembodiment of the [rational] masculine perspective is itself an inscription of a body, a body which is so comfortable we needn't know it is there, a body which is simply a home for the mind, and doesn't interrupt it, confuse it, deceive it with irrationalism, or bleeding, or pregnancy. (Ahmed 1995, p. 56)

\section{Critical Approaches to the Disembodied Criminal Subject}

For the most part, critical legal theory has sought to expose the rational, reasonable, responsible criminal subject as one that invariably espouses male, heterosexual, middle-class, liberal sensibilities that, when universalised, produces a law that excludes and marginalises interests and experiences that do not align with this prototype (Norrie 2014; Byrne 2003; Carvalho 2017, p. 23-50; Naffine 2019; Ahmed 1995; Chandra-Shekeran 1997). In the most serious cases, the rational, 
reasonable, responsible subject has served as a benchmark for confirming the inhumanity of others, leading to their wholesale expulsion from the political community and their maltreatment under the law (Razack 2008).

In Unspeakable Subjects Nicola Lacey considers the exclusionary tendencies of a law of sexual assault that is founded on a disembodied notion of subjectivity. She writes that, absent any discussion of the affective and bodily dimensions of sexual violence, the criminal law commits itself to a rational, penetrative, coercive, propertied, commodified understanding of sex and sexual autonomy which privileges heterosexual male sexuality. She writes that, in adopting this sort of disembodied perspective, the law elides the fact that "both the "normal" and "deviant" sexualities of those with male and female bodies are very different' (Lacey 1998, p. 51), and that these differences matter because they influence our understanding of what makes rape wrongful. In the way that the law of rape is organised, we are given the impression that bodies with penises have a biological predisposition for coercive, penetrative sex, and bodies with vaginas are its passive recipients. This is the natural order of things. In this way, the criminal law actively produces 'normal' bodies by reference to its own liberal humanist agenda, and attributes bodily performances that align with this view, to biology;

only subjects with normal bodies can claim full legal privileges, including, on occasion, the privilege of corporeal invisibility. In other words, having a 'normal' body allows a subject to fit the culturally privileged model of the rational choosing individual. (Lacey 1998, p. 55)

Lacey's work not only addresses a key gap in traditional feminist legal theory, but also within critical legal theory more broadly, both of which privilege sociohistorical interpretations of the body; the idea of 'gender', for instance, while leaving its biological constitution, its physicality, 'sex', untouched. The problem with legal critiques that are grounded in the sociology of the body is that they too often believe that the contingencies of the 'human' can be exposed simply by focusing on the body's sociality (Murphy 1997). As a result, what most critical accounts end up concluding is that "what needs to change are the attitudes, values, and morals' that we attribute to certain kinds of bodies, 'rather than the [normal] body itself' (Grosz 1994, pp. 15-17). Collectively, the turn to corporeality is grounded in the view that

the body, or rather bodies, cannot be adequately understood as ahistorical, precultural, or natural objects in any simple way; they are not only inscribed, marked, engraved, by social pressures external to them but are the products, the direct effects, of the very social constitution of nature itself. (Grosz 1994, p. x)

There is no, as Grosz explains, 'real', 'material' body that precedes its historical, cultural and social representation.

In the section that follows, I interrogate how the disembodied subject of the law of homicide and assault is a biologically determined one. Consequently, while the criminal law may claim to be blind to race, gender, culture, sexuality, 
all the ways in which we inscribe bodies with meaning, its turn to the biological body, the body that is there but also not there, is nonetheless exclusionary because it gives us an account of how 'normal' bodies 'naturally' behave when subjected to violence. Farmer speaks to how deeply ingrained this incorporeal vision of the law is when he claims that the key focus of critical approaches to the criminal law should not be the 'content or value of the law' itself, but 'the relation between the criminal law and its object' (Farmer 1996, p. 59). From his view, then, the value of critical methodologies lies in its capacity to pick apart and expose the contingencies of the very thing that the criminal law takes for granted (its 'object', rather than its 'subject'), the very thing that it sees as passive, neutral and unchanging; the very material conditions which justify its intervention.

In interrogating the law of homicide and assault, I have set myself the task of bringing to light two things. First, that death and injury, the 'harms' upon which the criminal law justifies its intervention, are not the neutral, passive, natural conditions of the body that the criminal law's reference to biology insinuates. Death and injury are not things that happen to bodies. They are epistemological devices by which what happens to our bodies is made coherent, given legal meaning and saddled with consequences. Under the criminal law, death and injury are material-discursive constructs. They are contingent, flexible, active phenomena that are sedimented, materialised, and naturalised through a range of practices that make them 'senseable', by which I mean visible, audible, olfactoral, tangible, for us. By examining a range of discursive practices that have become common to criminal legal proceedings, I expose how death and injury are brought into being, how they are enacted as biological 'facts', as visible, material, data, by the criminal law. Over time, and with repeated use, these materialising practices come to be seen as evidence of how human bodies perform violence; in fact, how bodies must perform violence to be recognised as the 'human' subjects of criminal law.

The second idea that I hope becomes clear through my analysis is that, while the criminal law has become accustomed to speaking about the wrongfulness of violence by reference to abstract disembodied principles such as autonomy, agency, and self-determination-encoded within the architecture of homicide and assault as concepts like 'consent' and 'intentionality'-it conveniently neglects their corporeal dimensions; its real, in-the-world performances and effects. Criminal law abstracts consent from the material conditions of its operation and, in the process, misjudges what makes violence wrongful for us. It is not merely its non-consensual nature that makes violence reprehensible, but the fact that its commission stops us from doing things, forging relationships, engaging in interactions that we desire. We feel vulnerable to violence because it has the potential to cause us pain, fear, anxiety-all of which shapes how we appear to the world and interact with it. Consensual violence, by the same token, would still be perceived as immoral or unfair, if it had these same consequences. In the way that consent operates within the criminal law, therefore, draws our attention away from these lived realities of violence, and operates on the base assumption that what makes us, as human beings, vulnerable to violence can be attributed to the body's biological limits. This invariably produces an understanding of consent that is misguided, for it assumes that, apart from conditions in which the body is physically threatened, consent is unproblematic. Accordingly, the idea I 
wish to draw attention to through this analysis, is how a law of homicide and assault that traces human vulnerability exclusively to biology, does not fully account for what makes violence wrongful and harmful for us, as embodied entities.

\section{The Material-Discursive Enactment of Death and Injury}

The statutory provisions and common law definitions of homicide and assault tell us very little about the proscribed harms of death and injury. As crimes that have been described as mala in se, moral wrongs, actions that can be considered wrongful independently of being legally prohibited, the criminal law presumes that death and injury, at least in terms of its physical manifestation (which is what engages the criminal law), has the same consequences for all of us. Indeed, this is an idea that continues to hold strong in spite of the fact that the common law tells us that what constitutes physical death and injury is highly controversial, historically contingent and remarkably dependent on the prevailing diagnostic tools and technologies that societies have at their disposal.

At different points in English legal history, death has been affirmed by the absence of a perceptible breath and pulse; an irreversible loss of consciousness/awareness; a cessation of all (but sometimes only higher) brain activity; and/or irreparable damage to the cardiorespiratory functions of the body (Smith 1985; Rodabough 2003). Despite this variance, however, Smolensky has tellingly noted that as a society we have always found legal definitions of 'life' far more contentious and varied then legal conceptions of 'death' (Smolensky 2006). In so claiming, she alludes to liberal law's privileging of an agentic and animate subject as the paradigmatic bearer of rights. We care less about death because we have come to recognise the dead body as posing less of a legal burden than a live one.

Injury enjoys a similarly murky and ill-defined presence within the common law of assault. English Courts have, on the one hand, declared that bodily injury requires 'no explanation' and has an 'ordinary meaning' (DPP v. Smith [1961]; R v. Morris (Clarence Barrington) [1997]); while on the other, they have sought to sketch out its limits by reference to 'hurt', discomfort ( $R v$. Donovan [1934]), and damage that has no social utility ( $R$ v. BM [2018]). There is even little agreement about what constitutes more serious forms of assault, for while the Courts have declared that Grievous Bodily Harm is assault that gives rise to 'really serious harm' (DPP v. Smith [1961]; $R v$. Janjua [1999]), they have also qualified this by stating that this need not be 'life threatening, dangerous, permanent, [or] require medical treatment' ( $R$ v. Bollom [2003]).

In different cases, at different times, the Courts have interpreted 'bodily harm' as bodily injuries resulting in internal bleeding and broken bones (JCC v. Eisenhower [1984]), visible physical injury (e.g. wounding), illness or infection ( $R v$. Dica [2004]) and psychological trauma ( $R$ v. Bollom [2003]). These multiple, sometimes incoherent, ways in which injury has been conceptualised by the criminal law suggests that, contrary to the House of Lords' declaration, injury, in fact, has no ordinary meaning and requires much explanation. From the way in which assault has 
been adjudicated, it is clear that, for biological bodies that 'naturally' injure, injury's appearance under the criminal law is anything but stable, ahistorical and immutable.

And it is not that the words of judges bring 'death' and 'injury' into existence on their own. Forensic pathology, medicine, neuroscience, entomology, psychology collaborate with the criminal law to enact death and injury through their study of the body. Like the judge's words, neuroimages, autopsy reports, x-rays, videorecordings, photographs, slides containing human-tissue infested with insect larvae, psychiatric evaluations are just some of the discursive practices through which death and injury come into being during the criminal trial; and how they become sense-able phenomena (Gilani 2020). These materialising practices give us a visible, olfactoral, tangible, audible account of what happens when knives, bullets, cars, other bodies, and the environment connect with human flesh. Together they give structure and form to the dead and injured body.

Crime scene photographs materialise death and injury as bodies that are immobile (in some cases irreversibly so) and silent (Redmond 2018; Scott 1945). They are leaking, shrieking, begging, flinching bodies, with contorted faces (Baynes 2017; Loweth 2020). The words of judges tell us that an injured body is one that is aesthetically different, sometimes aesthetically displeasing. ${ }^{2}$ Coroner's reports, x-rays, and CT scans enact death and injury as bodies whose parts and/or organs have been rendered dysfunctional, damaged, or all together non-operational (Scott 1946; Chief Coroner's Guidance and Sheets 2019). Entomological and forensic analysis bring death and injury into being as bodies whose flesh has disintegrated into its most basic elements, bodies that have become infested by the environment and have the potential to contaminate 'normal', 'living' bodies (Wakefield 2010; Health Protection 2010). The violated (and violating) body leaves traces of its presence long after it disappears (Nakashima 1995; Libal 2014).

Nevertheless, these different modes by which the body is studied do not provide us with an objective, natural account of what happens to the human body when it suffers violence. There is always a 'normal' body that underwrites their findings and thus constrains and enables what can be said about the violated body. This is an image of the body that finds resonance within liberal humanist philosophies which see the immaterial mind (the brain at its centre) and cognition, as the seat of human identity and subjectivity, while the body becomes its material substrate; the 'sensing' matter through which the mind is actualised. The 'normal' body is one which gives the mind-wherein lies the true essence of human nature-a 'being in the world' existence (Kant 2007, Introduction). From this view, human existence crystallises in the form of an integrated mind-body; bodies that 'exteriorise', they move and perform, what is in their 'interior', both in terms of bodily action but also emotion (Spinoza 1992, Part III). For liberal humanists, it is the mind that is the basis of moral decision-making, and while it may take the body into consideration, it is more than capable of doing this in abstraction from the body as well (Hobbes 2016,

\footnotetext{
2 The Courts in $B M$ enacted the inhuman body of the victim through its description of a body modification procedure involving tongue splitting as having 'an effect similar to that enjoyed by reptiles' (R v. BM [2018], 560).
} 
Chapter VI; Kant 2007). The 'normal' body thus becomes one that acts in accordance with the mind's decisions. And clearly, we have seen that this is precisely the kind of body that informs the criminal law, given the structuring of offences around the concept of mens rea and the organisation of the violent offences so that they look to consent and intention as the underpinning rationale for human action.

Consequently, what the neuroimage, x-ray, or photograph tries to do in the context of the criminal trial cannot be separated from these wider philosophical discussions about the mind-body relationship, because what the criminal law perceives as the 'normal' body, the body that it is so 'comfortable' with that it becomes invisible, frames these materialising practices. To give one example of how it does this, we can turn to the law of criminal evidence. The criminal law enables and constrains what can be said about the body by its rules of evidence, which determine the validity and admissibility of forensic and medical knowledge based on its reliability - the extent to which it aligns with existing knowledge and research, taking into consideration the qualifications of its researcher, and whether its results can be verified by others (Merlino et al. 2007). Couched in these terms, the images of the body that are permitted to become part of the criminal legal narrative take on the status of objective, neutral, and genuine portrayals of reality; snapshots of how the body actually exists.

And so, all the while the criminal law and its attendant discourses produce the violated body, the body in pain, the body that has been wronged, the body that is the object of legal intervention, they also simultaneously give an account of the criminal law's ideal subject. Against a violated body that is shrieking, leaking, and immobile, is the foregrounding of a 'human' subject that is rational, animate, agentic. A human subject who is in possession of an organic, seamless, continuous body. I am hoping that, by exposing how the injured and dead body is a material-discursive construct, by drawing attention to its philosophical moorings, the violated body can be revealed as a 'matter of concern' (Latour 2004) for the criminal law. Because, as a matter of concern, the dead and injured body may be opened up to critique in a way that 'matters of fact' never can.

What is the value, particularly to the criminal law, of opening up the dead and injured body to scrutiny? As Murphy and Lacey suggest, in abstracting the mind from the body, the criminal law loses sight of what makes violence wrongful for us. If nothing, this neglect in the criminal law signals its own limitations, its own nonreceptiveness to the state of human relations, and most certainly, as many critical legal theorists have already argued, it brings to light the criminal law's own exclusionary potential. Let me illustrate by way of an example.

In her poignant exegesis of a Canadian criminal trial involving the sexual assault and murder of an Aboriginal woman Pamela George, Sherene Razack reveals how the Trial Court judge interpreted the victim's consent to engage in risky sex work as muddying the distinction between consensual and non-consensual activity. Unable to determine with any certainty whether Pamela was coerced into, or consented to, sex with her murderers, the Court felt it had no choice but to absolve the defendants of liability for rape (Razack 2002). The criminal law's focus on consent as the paradigmatic account of human agency, self-determination and autonomy, and as the basis of wrongfulness in cases of sexual assault, entirely obscures the fact that we, 
as embodied beings, find rape evil because it controls how we perform and experience our bodies. It hurts, it humiliates, it takes a bodily experience that is meant to be pleasurable, intimate, and private, and turns it into a painful, fearful, public spectacle. Rape constrains how we express and impress ourselves upon the world. From this view, even consensual sex can be wrongful if it has these effects. And these effects of rape cannot be captured, cannot be ascertained without a consideration of corporeality; without a historical, spatial, relational positioning of the body. Yet, the criminal law expects a disembodied 'consent' to carry this moral burden. When the Court used Pamela George's consent to engage in sex work as the defining basis of her rapists' liability, it treated her body as being equally vulnerable to sexual violence as every other body. It failed to take into account the intimate relationship between volition and corporeality; the situatedness of consent. Pamela's capacity to consent was constrained, as Razack explains, by her body's presence in a dangerous area within the city of Regina; a presence framed by a history of colonial exclusion, racial difference, and economic deprivation, all of which bore down on her encounter, as a visibly Aboriginal woman, with the young, White, middle-class men charged with her rape and murder. The harm of her rape needed to be situated within these entangled and intersecting materialities that rendered her body invisible, even before it became the object of violence (Culhane 2003). In abstracting Pamela George's consent from her body, the criminal law suggests that her consent holds the same value and meaning to the consent expressed by a 'normal' body, in a 'respectable' place, doing 'decent' things, when it is clear that it never can. By treating death and injury as biological facts, rather than mediated phenomena, the criminal law allows the injured and dead body to fade into the background and, as a result, falls short of recognising precisely how intimately the criminal law is itself entangled in producing the kind of violated body that it desires; the kind of body that supports its own liberal humanist exercise of power.

\section{Violent Affects and Bodily Performance}

There is one last idea I want to discuss here, and that it is the performative dimensions of death and injury. I have already considered how death and injury are mattered through epistemological artefacts such as the judge's words, crime scene photographs, and x-rays. But they are also mattered, or come to matter to us, by the affective responses these artefacts invoke. The ways they compel our bodies to behave in response to them. Death and injury are in a sense, lived realities even for bodies that are not the direct recipients of violent blows and stab wounds. One way in which our bodies perform death and injury is through the affective response of disgust and the visceral physical reactions that it generates. Encountering violence affects us. We come to judge the 'wrongness' or 'immorality' of an event by our body's reaction to it. For most of us, our bodies behave in uncontrollable, undesirable, uncomfortable ways when confronted with violent spectacles (Kekes 1992, p. 433).

Our affective experience of disgust tells us two things. First, that we see similarities between the bodies we are encountering and our own, for disgust operates on 
the basis of not only empathy, "we bring ourselves to experience vicariously what [the victim] is experiencing personally' (Kekes 1992, p. 434), but also desire. We are repulsed by that which we imagine as bodily excess and abjectness 'excretions, waste products, and bodily by-products' (Grosz 1994, p. 81); that which we both expel from the body but in which we are still psychically invested. Disgust gives us a visceral account of the normal subject with its bounded body, privileged functions, along with its 'abject'; the parts, functions, experiences that may be there, but should never be seen or felt (Grosz 1994, p. 192); the parts that exist, but do not 'matter'. And second, since disgust enables restraint (i.e. we avoid encounters that repulse us), it is also indicative of a kind of embodied morality. Disgust, and the horror that it perpetuates, thus sets out the boundaries between what we see as acceptable and unacceptable encounters.

Scholarship about the effect of 'gruesome evidence' in the courtroom suggests that repulsion and disgust are ways in which parties to criminal legal proceedings affectively encounter death and injury with and through their own bodies (as elevated heart rates, sweating, emotion, nausea, fainting) (Bright and Goodman-Delahunty 2006; Grady et al. 2018; Baynes 2017). Disgust is thus an embodied (and embodying) experience. As some authors have argued, the power of corporeal disgust in the context of a criminal trial is dangerous for it has the tendency to override cognitive 'rational' decision-making, and can significantly alter how juries make decisions about culpability and sentencing (Hendrick and Shaffer 1975). In this sense, the death and injury that is enacted through the criminal legal process, as a performed encounter, is one that is again mutable and illusive; it is an encounter whose full moral meaning cannot be captured with any certainty, without a turn to the body; it is an encounter that remains largely concealed, but also unchecked, by a criminal law that has no theory of the body.

\section{Bionic Bodies and Posthuman Violence}

In the previous section of the paper I have argued that the biological body that informs the law of homicide and assault is a socio-culturally mediated body. It exercises power by constraining and enabling how we think about, perform and see violated bodies. Nevertheless, as I intend to demonstrate here, it is an understanding of the body that, given the breadth and depth of emerging biotechnological innovation, will soon need revisioning. The continuous, organic, coherent, 'fleshed' human body is soon to become a thing of the past. For some futurists and posthumanists it has already become a thing of the past (Kurzweil 2005; Craelius 2002). The technological 'singularity' that they speak of, for many posthumanists, represents a further unrooting of a 'human' that has never been quite as stable and coherent as we would like to think. Emerging biotechnologies, the internet age, artificial intelligence, changing environmental conditions, recognition of animal rights, have all forced, in one way or another, a rethinking of what it means to be 'human' and a (re)configuration of the boundaries which separate the human from the nonhuman world (Gane 2006; Hayles 1997; Braidotti 2013; Haraway 2016). For posthumanists like Braidotti and Haraway, this constant (re)negotiation of the outer limits of human 
existence and subjectivity has been described as part of the human's ontology (Haraway 2016; Braidotti 2013). It is in our nature to be nebulous, murky, ill-defined, morphing creatures. That is the ultimate exercise of 'human' agency: to defy categories that temper our becoming and wrongly present us as being. Nevertheless, with the recent digital and biotech revolution, the expected transformations promise to be so profound, humans are likely to become so integrated with machine technology, that distinguishing human from nonhuman, organic from inorganic bodies, will become impossible in as little as a few decades (Bostrom 2011; Savulescu et al. 2011). Human bodies will no longer be vulnerable to the same sorts of experiences and bodily risks to which our fleshed bodies have become accustomed. In the following sections of the paper I explain how death and injury, as material-discursive constructs, firstly, opens up new, non-anthropocentric, channels of thinking about homicide and assault; secondly, why this thinking is crucial given the emergence of bionic bodies; and lastly, how we might imagine criminal violence using the insights of posthuman theory and new materialism.

\section{Bionic Bodies and Hybrid Corporealities}

What is the bionic body? Here I use the term 'bionic' to describe human bodies that have undergone (or have the capacity to undergo) augmentative and curative procedures that use technology to enhance and supplement the natural capabilities of the body, and/or to correct or diminish the effects of its existing physical/material limits. These are bodies that can be described as corporeal hybrids, where the interplay between organic and inorganic elements, the introduction of flesh to curative and augmentative medical and scientific procedures, are likely to lend themselves to embodied experiences that are different, sometimes antithetical to those of the organic, fleshed body.

The technologies that I speak of range from the radical and experimental, to the banal and already existing. Let us first begin with the more extreme and speculative technologies. For several years now, organisations such as Alcor have been involved in the cryopreservation of human corpses and heads in the hopes that either bodies may be revived in the future or their brains can be emulated and placed into synthetic bodies (Bostrom and Sandberg 2009; Alcor: Life Extension Foundation 2020). While the reanimation of cryopreserved bodies has been charged with being a speculative 'pseudoscience', whole brain emulation (WBE) has become an area of substantial mainstream research. In fact, prominent futurists Nick Bostrom and Anders Sandberg have given us a 'roadmap' of how WBE can be achieved (Bostrom and Sandberg 2008), and they believe that, by 'enabl[ing] back-up copies' of our brain, WBE will allow human beings to attain a kind of 'digital immortality' (Bostrom and Sandberg 2008, p. 5).

Researchers interested in WBE are already beginning to create interface technologies which, through the implantation of small fibres in human brains, can help us achieve symbiosis with machine intelligence. If brain-machine interfaces and WBE are ever realised, they could help enhance human sensory experiences, boost our memory and thinking, and allow us to achieve a disembodied or 
differently-embodied existence (Verhoeven et al. 2015). Some researchers have even noted that brain-machine interface technologies, and the artificial neural networks they produce, may facilitate the recovery of sensory and motor functions in patients suffering from nervous-system injuries and/or limb amputation (Thakor 2013). If the future of human existence is one which involves the placement of our minds in synthetic bodies, the linking of our brains to machines, and the restoration of functioning to organic limbs that have been irreversibly damaged, bionic bodies will likely manifest violence in very different ways than biological ones. Furthermore, the availability of these curative and augmentative procedures will also mean our physical vulnerabilities to the environment, other bodies, and objects, will need re-evaluating.

While WBE, cryonics, and brain-machine interfaces seem to point to a reality that is more suited to the annals of science fiction novels, centuries away from being realised, the use of body enhancement and curative technologies such as artificial limbs, wearable computers, synthetic organs, and bio-printed tissues are technologies that are either already in use, or years (rather than decades) away from being actualised. We already live in a world where many of our limbs can be replaced by synthetic substitutes and organ functions can be outsourced to technology (Murphy and Atala 2014). Prosthetic body parts are continuously being improved so that they are more comfortable, are aesthetically similar to and better integrated with the organic human body, and can perform the same tasks as organic limbs with similar or even better levels of precision (Ersek and Beisang 1991). We even have, and have had for quite some time, body extension devices, like the wheelchair, which can perform bodily tasks without being directly fused or attached to the physical bodies of their users, and which researchers report as crucial to their users' overall body schema and image (Standal 2011).

These technologies are not only recomposing the material, physical 'stuff' of our bodies, but also our sense of self. In Bodies, Commodities and Technology, Sharp writes about how organ transplantation, and the fact that biological organs may soon be replaced with synthetic ones, are transforming our ideas about the integrity of the body and its 'personalness' (Sharp 2007, p. 4). Similarly, Wilson highlights how a world in which the organic body is the norm, but evolving augmentative technologies are making a 'superhuman' future possible, is producing a 'divided consciousness' among prosthesis wearers; they yearn for a superhuman cyborg future while simultaneously feeling estranged from and disgusted by 'this alien presence in [their organic] body' (Wilson 1995, p. 246; Zylinska 2002, p. 215). In a society structured around liberal humanist accounts of identity and personhood, where human existence is synonymous with the presence of a bounded, continuous, organic body that is under the complete control of its possessor, the prosthetic body undermines the very principles of autonomy, agency, and bodily integrity that define us as human beings under such a system. For many of us, our bodies are who we are. The fact that we can be estranged from parts of it, reattached to parts that once belonged to other bodies (and thus 'persons'), even other species (Rahmani et al. 2019), and now the fact that these parts can be replaced with mechanical or synthetic substitutes, has significant implications for how we imagine our place in the world and 
our relationship to other bodies and things. Particularly in a world that has always reverberated with signs of human exceptionalism and superiority.

In terms of what the bionic body means in the context of violence, clearly these technologies are redefining the actual physical limitations of the body. As our bodies become machine, how we think about, experience, and perform death and injury changes. We will, and already have to some extent, bodies that do not bruise, bleed, leak, wound or sense pain in response to being hit, battered, bludgeoned. Soon, we may also have bodies that do not die the way medicine and law expects them to (e.g. death as the irreversible loss of cardiorespiratory function and brain activity). These new realities are further bringing to light precisely how mutable, flexible, and socioculturally mediated the biological body is.

As I explained earlier, these changing material conditions are also likely to have an effect on how we experience vulnerability to violence and, in connection with this, the wrongfulness that we attribute to homicide and assault. To give one example, researchers comparing users of passive prosthetics (limbs which are fitted over an amputated joint) versus osseointegrated prosthetic limbs (limbs which are directly and permanently anchored to the human skeleton) found that the latter's self-perception changed from someone who is disabled to someone who is healthy once their limb was attached (Lundberg et al. 2011, pp. 210-211). However, these same users reported being more fearful of injury to their prosthetic limb than passive prosthesis users. Many of them even claimed that injury to their prosthetic limb would leave them feeling 'more handicapped [emphasis added]' than when they were an amputee with no artificial limb (Lundberg et al. 2011, pp. 209-210). Thus, in considering one's vulnerability to violence, one could argue that the osseointegrated prosthetic wearer occupies a liminal position between the amputee with no prosthesis and a person with organic limbs, because someone whose limbs have been replaced, even though those limbs have become part of their 'healthy' body schema, is someone that is, if not less, then certainly differently vulnerable to violence than someone with organic limbs. At the same time, the osseointegrated prosthesis wearer's vulnerability to injury cannot be considered identical to passive prosthetic limb wearers. While both have had limbs that have been replaced with artificial substitutes, the fact that osseointegrated limb users perceive themselves as 'healthy' in comparison (and thus fear injury if not more, then certainly differently, than passive prosthesis wearers), is likely to have a bearing on how they experience violence and the meaning that they (as well as others) attribute to it. Thus, in order to fully appreciate the moral meaning that attaches to an experience of violence, we must take not only corporeality-and its embodied experience of violence-into account, but must also treat human vulnerability as relational; human bodies and their experiences are given meaning by reference to other (normative and non-normative) bodies, matter, and the environment. In the section that follows, I draw on posthumanist and neomaterialist theory to develop this idea of an embedded, embodied, relational idea of human existence and use it to think about how best to reposition a criminal law that has long been structured around a normative body that bruises, tears, bleeds, screams in pain when it is battered. How can such a criminal law be made more responsive to violence against bodies that do not perform death and injury in the same way? 


\section{Posthumanism as an Ethics of Non-anthropocentricity}

In the humanities there is now widespread consensus that being 'human' is historically contingent and socio-culturally mediated. Feminist, critical race, and postcolonial scholars have long exposed how the rational and reasonable Man has, at different moments in our history, consigned racial-, cultural- and gender-minorities to sub-human or non-human status (Phillips 2015; Fanon 1986; Spivak 1988; Ahmed 1995). Recently, these debates have also set the stage for critiques of the Anthropos, inspiring a new wave of critical theory which sets out to challenge human-centred discourses and expose how non-human matter and technology challenges liberal humanist framings of (hu)Man, as a self-contained, discrete, universal subject (Hayles 2008; Haraway 1991; Badmington 2003; Ferrando 2013). For some, these contingencies further expose the ever-present human potential for transformation; we are simultaneously human, but also always posthuman (Braidotti 2015; Hayles 2010).

Part and parcel of this posthuman shift has been a growing recognition that human existence is entangled within, conditioned by, intra-actions that are taking place between a whole host of other things, ideas, and matter in our midst. New materialists such as Kirby, Mol and Barad draw attention to how matter and meaning are co-constituted; how matter does not simply exist—passively lying there awaiting human intervention— but how it is enacted, brought into being, through social practice and performance. For this reason, all matter possesses transformative potential; how it matters can, and does, change depending on the context of its emergence (Barad 2007; Mol 2002; Coole and Frost 2010; Kirby 2018). Matter has agency in this sense; it moves and affects, and has the potential to enable and constrain human action (Bennett 2010). Arrangements of matter have also been described by some posthumanists as capable of exercising rational action, even cognition, features that have historically been isolated as exclusively 'human' (Hayles 2017; Bennett 2010; Barad 2007).

Posthumanists and neo-materialists both then question what it means to "be human' in a system where everything has the potential to exercise 'human' capacities; and where 'human' agency is deeply embedded within the environment in which bodies act, and those environments are themselves organised on the basis of prevailing ideas about the ways our bodies can and should act. In short, these lines of theoretical inquiry have emerged as a critical response, but also as Barad and Braidotti would argue, an 'affirmative' response, ${ }^{3}$ to emerging social trends that compel us to not only consider the extent to which Enlightenment Humanism's Man has simplified, essentialised, and valorised human expression, identity and existence, but to aspire to an ethics that takes into account these entanglements between the human and non-human, where our fate is shaped by more than just human intention and creativity. For many posthumanists, then, the potential for change, transformation,

\footnotetext{
3 In the sense that 'critical' simply deconstructs while the aim of posthumanist and new materialist literature is to highlight convergences between the past and now in order to produce a more ethical politics (Braidotti 2019, p. 19, 36).
} 
(re)configuration is part of the human's ontology. We are nomadic subjects (Braidotti 2011), 'impure' cyborg subjects (Haraway 1991); we shift, we change, given the (human and nonhuman) bodies, things, ideas, we come into contact and form associations with (Delanda 2016). And these interactions do not only shape our 'insides', our psyches and the way we think, but also, the matter of our bodies. Being human is having the capacity for 'morphogenesis' (DeLanda 1997).

For posthumanists and neo-materialists, the presence of the bionic body then is precisely one more example of the evolutionary nature of 'the human' and how human-centred discourses, liberal humanist accounts of subjectivity and agency, no longer speak to the current state of affairs. In fact, according to antihumanists, liberal humanism has never spoken to the state of human affairs, but has always been a dehumanising discourse that has used the human/nonhuman distinction to withhold rights and protections from those designated as Other (Braidotti 2015, pp. 16-25). Nevertheless, what is clear is that posthumanists demand that we recognise this shifting, always becoming, attribute of human existence as part of who human beings are. We are, by nature, impure, evolving, mutating subjects and our understanding of the (corporeal, physical, philosophical) boundaries of 'the human' ought to reflect this. It is this kind of affirmative ethics that I hope to contribute to in bringing posthuman theory to bear on the criminal law.

\section{Posthuman Violence and the Criminal Law}

The idea to question how inorganic and bionic bodies engage the criminal law is not entirely new. Gowri Ramachandran, for instance, has queried to what extent the criminal law should adapt its understanding of harm to account for artificial body parts and body extension devices such as prosthetic limbs and wheelchairs (Ramachandran 2010). She writes that the 'social, as opposed to the pre-social, body is the body that matters, and the social body extends beyond organic, human, continuous material to inorganic, non-human, discontinuous entities' (Ramachandran 2010, p. 253). In light of this, her proposed solution is that the law should look at how injuries to the prosthetic arm, the nonhuman and discontinuous body 'are analogous to injuries inflicted on organic' ones (Ramachandran 2010, p. 257). This means that if injury to the prosthetic limb or inorganic body part stops the body from performing the function that the prosthesis was meant to restore or enhance, it may be possible for the criminal law to find liability for assault and battery. The usefulness of the inorganic body part (what Ramachandran refers to as the 'social body'), continues to be determined by reference to the functions and aesthetics of the normative 'presocial body'.

What is problematic about Ramachandran's proposal is that, by protecting the bionic body only to the extent that it demonstrates the same sets of vulnerabilities as the normative, presocial body-by showing that that wounds to their limbs and damage to their bodies results in the same existential threat to their being and personhood-we lose sight of the fact that the criminal law's normative body is itself a discursive-material construct. It is a materialised body that is laden with meaning and consequences that even organic bodies cannot live up to. Thus, what needs to 
change is not how we see the bionic body in comparison to the biological one, but how the biological one itself does not account for the diversity of human experiences of violence; how the biological body enables and constrains what we are able to feel, and how we may think, about homicide and assault. And, more importantly, that this allows the biological body to limit who the criminal law recognises as capable of being violated.

So how must one address this impoverished state of the criminal law on violence? A crucial first step might be, as Orlie's reading of Nietzsche suggests, that we think about our turn to the criminal law as reflective of a human desire to make the impersonal - the capricious, random, world-in-flux - intelligible, coherent, and meaningful; in other words, 'personal' (Orlie 2010). From this account, when it comes to violence what we fear and what we are vulnerable to, is the unknown, the unpredictable; we experience anxiety when confronted with a world that is arbitrary and random. A world that appears not at all concerned with us, as individual subjects. To date, the criminal law has imagined this vulnerability as a fear of non-existence and has sought to allay our anxieties by fixing our bodies using biology and universalising human experience. This has produced a legal understanding of violence that is deeply tied to the normalisation of a material body that has a particular form (e.g. flesh-and-bone, possessing organs and skin), that performs violence in specific kinds of ways (e.g. leaking, breaking, contorting, screaming), and ascribes those experiences with a specific set of meanings (e.g. loss of autonomy, coercion, violation of self-determination, cessation of 'self').

But this does not have to be the way in which the criminal law makes the impersonal, personal, and posthuman insights can help in that regard. What the criminal law should aspire to is not an understanding of the human subject that is transcendental and exceptional, but an immanent subject that is embodied, embedded, and relational: a subject whose subjectivity is bound up and entangled in the world around it; whose materiality is practiced, plastic, and relational. And a subject whose differential experiences, given these diverse materialities, result in varied, flexible, continuous, but always incomplete, becomings. To be 'human' is, by its very nature, a subjectivity that is always in the process of becoming with the world. Being human is being impure, hybrid, and liminal. The impersonal can be made 'personal' by relating us to the world, rather than estranging us from it. For, as Orlie writes, '[o]ne of the vicissitudes of our development of a fantasy of ourselves as distinct persons is a sense of alienation from all of nature of which we are actually part and parcel' (Orlie 2010, pp. 132-133). Drawing on Nietzsche's Good and Evil, she writes that human "freedom and creativity are exercised when we "learn more fully" what is "firm and settled" and recognise it as the accidental, the meaningless, raw material out of which we can make virtues and values' (Orlie 2010, p. 125). In my view, a criminal law that is more attuned to this fear of impersonality recognises, rather than attempts to temper and control, that 'being human' is materialised through enactments, performances, imaginings that take place in concert with, sometimes in conflict with, but always in relation to different bodies, other matter, and prevailing ideas; the human 'subject is not a substance, but rather a process of negotiation between material and semiotic conditions that affect one's embodied, situated self' (Braidotti 2013, p. 75). 
In light of this, a posthuman notion of violence, then, would be one that sees death and injury as processes (rather than physical states) of instrumentalization and objectification - an understanding of violence that speaks to its harmfulness by reference to the body's phenomenological experiences rather than by identifying the presence of arbitrary physical conditions. A body capable of being killed and assaulted must be thought of as, using Deleuze's term, 'a body without organs', a body that has an infinite and unlimited potential for becoming dead and injured because it is a body that is enacted through different processes, means, and modalities (Deleuze and Guattari 1987, pp. 175-178). If the true harm of death and injury is, as Feinberg explains, all the many moments that precede, yet move the body in the direction of extinguishing or rendering invisible its personhood, the suppression of its subjectivity (Feinberg 1986, pp. 79-80), then surely its failing organs, its lack of breath, its bleeding limbs, cannot be the moments which define homicide and assault's wrongfulness.

A posthuman account of violence broadly draws on a neo-materialist understanding of agency and freedom as practical exercises. As Grosz explains, '[i]f freedom is located in acts rather than subjects, then the capacity to act and the effectivity of action is to a large extent structured by the ability to harness and utilise matter for one's own purposes and interests' (Grosz 2010, p. 148). The wrongfulness of homicide and assault then stems not from the physical marks it leaves on bodies, but how its commission stops us from utilising bodies in the pursuit of our own desires, purposes, interests. Consequently, even if we are faced with a future in which bodies can be brought back to life, homicide would still retain its wrongfulness because it would not relate to the condition of life and death itself, but to how the treatment of the body's 'aliveness' or 'deadness' prevents us from relating to the world around us. Even if our bodies do not remain dead, homicidal violence makes our capacity to relate to the world around us dependent on the actions of others-desires, energies, forces beyond our control-to restore our bodies (and thus our subjectivity) to 'life'.

But all of this is not simply my way of saying that the criminal law requires revisioning because human bodies are becoming machine. Rather, the presence of the bionic human, I believe, compels us to question the ethical sensibilities that undergird the existing law of violence at this very moment. If death and injury have always been material-discursive constructs, then in what ways have these constructs constrained and enabled the exercise of human freedom and agency? Indeed, one way in which the criminal law has done so, and which I spoke about earlier, is the idea of a consent that is abstracted from the body and bodily experience. The criminal law treats its subjects as if they possess agency and freedom, rather than seeing agency and freedom as subjectifying practices themselves. The 'human' subject does not precede this performance but comes about as a result of it. And if this is truly the case, as I believe it is, then in failing to acknowledge this, the criminal law conditions the 'human' experience of death and injury long before, and long after, the actual physical infliction of violence itself. Bionic bodies only bring to light this continuing tendency of the criminal law to discern the human from the nonhuman, to privilege one set of material experiences and ways of being over others, and to make judgments about human existence and identity based on criteria which enable its own version of the 'human' to be universalised. 


\section{Conclusion}

This article has exposed how the biologically determined criminal subject forecloses important conversations about the corporeal dimensions of homicide and assault. In tracing the consequences of homicide and assault — death and injury-to the body's biology, the criminal law proceeds from the assumption that every (human) body is universally and equally vulnerable to violence. As a result, the criminal law sets itself the task of attending to the context in which death and injury occur, justifying its intervention on the basis of whether death and injury came about as a result of intentional and consensual decision-making. As universal 'matters of fact', the bodily dimensions of death and injury simply become part of the background conditions upon which the criminal law acts.

In the first part of the paper I have argued that the idea that death and injury are the natural, neutral, pre-legal consequences of violence is a misconception, and one that has been long-sustained by mistaking the modalities we use to observe, measure, relay and talk about the body, as indicative of the body's ontology. Thus, artefacts, like the x-ray, neuroimage, crime scene photograph, the coroner's report, the judge's words, the juries' bodily performances, do not so much affirm death and injury's presence, as much as they enact it; bring it into being by making it senseable to us. Our choice of the modalities we use to study and report the bodily effects of violence are themselves driven by prevailing social beliefs, cultural ideals, and emerging technologies. While the accounts of death and injury that the biological body makes possible are revealed as matters of concern rather than matters of fact, I argue that, through their repeated mobilisation and use, this has become an account of death and injury that has become comfortable to us. It has become difficult for us to recognise the presence of criminal violence in bodies that do not perform, or cannot be seen to perform, death and injury in these ways.

In the second part of the paper I explain how violence against the bionic body, on account of its hybrid corporeality, risks being elided or marginalised by the criminal law's privileging of the biological body and the universalisation of its embodied experiences. I argue that a more ethically sound criminal law would be one that accepts an embodied, embedded, and relational view of human vulnerability and determines the wrongfulness of violence by looking to the wider material conditions that not only expose us to the possibility of harm and attack, but constrain our capacity to express and impress ourselves upon the world around us. In my view, posthuman violence is indicative of a kind of concessionary acknowledgement that the 'here and now' has never been as stable, as inclusive, as coherent, as passive as we might have imagined it to be. Our understanding of violence, and its attendant materialities, has always sought to regulate, control, obscure, conceal the performances of some bodies, the exercise of some agencies, while privileging and emphasising others. Thus, a criminal law organised around a posthuman notion of violence would be one way of acknowledging these historical distortions and exclusions, and empowering bodies and agencies, in a world in which all matter, including the 'human' body, is embedded, embodied, and relational, and no action is independent or entirely personal. 
Acknowledgements I am grateful for the insightful comments offered by the two anonymous reviewers for Law and Critique. I would also like to thank Stephen K. Martin, Dr. Henrique Carvalho (Warwick), Dr. Anastasia Chamberlen (Warwick) and Dr. Sabrina Germain (City University London) for the engaging discussion and constructive comments offered during the planning stages of this article. The remaining errors are entirely my own responsibility.

Open Access This article is licensed under a Creative Commons Attribution 4.0 International License, which permits use, sharing, adaptation, distribution and reproduction in any medium or format, as long as you give appropriate credit to the original author(s) and the source, provide a link to the Creative Commons licence, and indicate if changes were made. The images or other third party material in this article are included in the article's Creative Commons licence, unless indicated otherwise in a credit line to the material. If material is not included in the article's Creative Commons licence and your intended use is not permitted by statutory regulation or exceeds the permitted use, you will need to obtain permission directly from the copyright holder. To view a copy of this licence, visit http://creativecommons.org/licen ses/by/4.0/.

\section{References}

Ahmed, Sara. 1995. Deconstruction and law's other: Towards a feminist theory of embodied legal rights. Social \& Legal Studies 4 (1): 55-73.

Alcor: Life Extension Foundation. 2020. https://alcor.org/BecomeMember/scheduleA.html. Accessed 17 May 2020.

Ashworth, Andrew, and Jeremy Horder. 2013. Principles of criminal law, 7th ed. Oxford: Oxford University Press.

Badmington, Neil. 2003. Theorizing posthumanism. Cultural Critique 53 (1): 10-27.

Barad, Karen. 2003. Posthumanist performativity: Toward an understanding of how matter comes to matter. Signs: Journal of Women in Culture and Society 28 (3): 801-831.

Barad, Karen. 2007. Meeting the universe halfway: Quantum physics and the entanglement of matter and meaning. Durham, N.C.: Duke University Press.

Baynes, Chris. 2017. Murder trial halted after court shown photos of mutilated victim so graphic juror passes out. 1 October. Independent. https:/www.independent.co.uk/news/world/americas/angel ikque-sutton-court-photos-mutilated-victim-ashleigh-wade-a7976451.html. Accessed 1 Oct 2020.

Bennett, Jane. 2010. Vibrant matter: A political ecology of things. Durham, N.C.: Duke University Press.

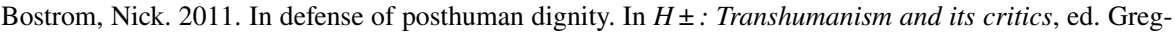
ory R. Hansell and William Grassie, 55-66. Philadelphia: Metanexus.

Bostrom, Nick, and Anders Sandberg. 2008. Whole brain emulation: A roadmap. Technical report \#200803. Oxford: Future of Humanity Institute, Oxford University.

Bostrom, Nick, and Anders Sandberg. 2009. Cognitive enhancement: Methods, ethics, regulatory challenges. Science and Engineering Ethics 15: 311-341.

Braidotti, Rosi. 2011. Nomadic subjects: Embodiment and sexual difference in contemporary feminist theory. New York: Columbia University Press.

Braidotti, Rosi. 2013. Metamorphoses: Towards a materialist theory of becoming. Hoboken: Wiley.

Braidotti, Rosi. 2015. Posthumanism. Cambridge: Polity Press.

Braidotti, Rosi. 2019. Posthuman knowledge. Cambridge: Polity Press.

Bright, David A., and Jane Goodman-Delahunty. 2006. Gruesome evidence and emotion: Anger, blame, and jury decision-making. Law and Human Behavior 30 (2): 183.

Byrne, Paula Jane. 2003. Criminal law and colonial subject. Cambridge: Cambridge University Press.

Carvalho, Henrique. 2017. The preventive turn in criminal law. London: Oxford University Press.

Chandra-Shekeran, Sangeetha. 1997. Theorising the limits of the sadomasochistic homosexual identity in $R$ v. Brown. Melbourne University Law Review 21: 584.

Chief Coroner's Guidance, Advice, and Law Sheets. 2019. Courts and Tribunals Judiciary. https://www. judiciary.uk/related-offices-and-bodies/office-chief-coroner/guidance-law-sheets/coroners-guida nce/. Accessed 15 Apr 2020. 
Coole, Diana, and Samantha Frost. 2010. New materialisms: Ontology, agency and politics. Durham, N.C.: Duke University Press.

Craelius, William. 2002. The bionic man: Restoring mobility. Science 295 (5557): 1018-1021.

Culhane, Dara. 2003. Their spirits live within us: Aboriginal women in downtown Eastsdie Vancouver emerging into visibility. American Indian Quarterly 27 (3/4): 593-606.

DeLanda, Manuel. 1997. Immanence and transcendence in the genesis of form. The South Atlantic Quarterly 96 (3): 499-514.

Delanda, Manuel. 2016. Assemblage theory. Edinburgh: Edinburgh University Press.

Deleuze, Gilles, and Felix Guattari. 1987. A thousand plateaus. Trans. Brian Massumi. Minneapolis: University of Minnesota Press.

DPP v. Smith. 1961. In AC 290.

Ersek, Robert A., and Arthur A. Beisang. 1991. Bioplastique: A new textured copolymer microparticle promises permanence in soft-tissue augmentation. Plastic and Reconstructive Surgery 87 (4): 693-702.

Fanon, F. 1986. Black skin, white masks. London: Pluto Press.

Farmer, Lindsay. 1996. The obsession with definition: The nature of crime and critical legal theory. Social \& Legal Studies 5 (1): 57-73.

Feinberg, Joel. 1986. The moral limits of the criminal law: Volume 1. Harm to others. New York: Oxford University Press.

Ferrando, Francesca. 2013. Posthumanism, transhumanism, antihumanism, metahumanism, and new materialisms. Existenz 8 (2): 26-32.

Gane, Nicholas. 2006. When we have never been human, what is to be done? Interview with Donna Haraway. Theory, Culture \& Society 23 (7-8): 135-158.

Gilani, Sabrina. 2020. On the discursive-material enactment of criminal violence: How death and injury come to matter to the criminal law. Law, Culture and the Humanities. Online First. 1-19. https:// journals.sagepub.com/doi/full/10.1177/1743872120966814. Accessed 23 Oct 2020.

Grady, Rebecca Hofstein, Lauren Reiser, Robert J. Garcia, Christian Koeu, and Nicholas Scurich. 2018. Impact of gruesome photographic evidence on legal decisions: A meta-analysis. Psychiatry, Psychology and Law 25 (4): 503-521.

Grear, Anna. 2015. Deconstructing Anthropos: A critical legal reflection on 'Anthropocentric' law and Anthropocene 'humanity'. Law and Critique 26: 225-249.

Grosz, Elizabeth. 1994. Volatile bodies: Toward a corporeal feminism. Bloomington, IN: Indiana University Press.

Grosz, Elizabeth. 2010. Feminism, materialism and freedom. In New materialisms: Ontology, agency and politics, ed. Diana Coole and Samantha Frost, 139-157. Durham, N.C.: Duke University Press.

Haraway, Donna. 1991. Simians, cyborgs, and women: The reinvention of nature. New York: Routledge.

Haraway, Donna. 1992. The promise of monsters: A regenerative politics for inappropriate/d others. In Cultural studies, ed. L. Grossberg, C. Nelson, and P. Trieichler, 295-337. New York: Routledge.

Haraway, Donna. 2016. Staying with the trouble: Making kin in the Chthulucene. Durham, N.C.: Duke University Press.

Hart, H.L.A. 2009. Punishment and responsibility: Essays in the philosophy of law. Oxford: Oxford University Press.

Hayles, N. Katherine. 1997. The posthuman body: Inscription and incorporation in Galatea 2.2 and snow crash. Configurations 5 (2): 241-266.

Hayles, N. Katherine. 2008. How we became posthuman: Virtual bodies in cybernetics, literature, and informatics. Chicago: University of Chicago Press.

Hayles, N. Katherine. 2010. What does it mean to be posthuman? In The new media and cybercultures anthology, ed. Pramod K. Nayar, 19-28. Chichester: Wiley.

Hayles, N. Katherine. 2017. Unthought: The power of the cognitive unconscious. University of Chicago Press.

Health Protection. 2010. ed. SI 2010/657 (Local Authority Powers) Regulations 2010, reg 11(1).

Hendrick, Clyde, and David R. Shaffer. 1975. Murder: Effects of number of killers and victim mutilation on simulated jurors' judgments. Bulletin of the Psychonomic Society 6 (3): 313-316.

Hobbes, Thomas. 2016. Leviathan. London: Routledge.

JCC v. Eisenhower. 1984. In QB 331.

Kant, Immanuel. 2007. Critique of pure reason. London: Penguin Books.

Kekes, John. 1992. Disgust and moral taboos. Philosophy 67 (262): 431-446.

Kirby, Vicki. 2018. What if culture was nature all along?. Edinburgh: Edinburgh University Press. 
Kurzweil, Ray. 2005. The singularity is near: When humans transcend biology. New York: Viking.

Lacey, Nicola. 1998. Unspeakable subjects, impossible rights: Sexuality, integrity and criminal law. Canadian Journal of Law and Jurisprudence 11 (1): 47-68.

Latour, Bruno. 2004. Why has critique run out of steam? From matters of fact to matters of concern. Critical Inquiry 30 (2): 225-248.

Libal, Angela. 2014. Fingerprints, bite marks, ear prints. Broomall, PA: Simon and Schuster.

Loweth, Jenny. 2020. First CCTV images released from Denholme murder trial. Bradford: Telegraph \& Argus.

Lundberg, Mari, Kerstin Hagberg, and Jennifer Bullington. 2011. My prosthesis as a part of me: A qualitative anlaysis of living with an osseointegrated prosthetic limb. Prosthetics and Orthotics International 35 (2): 207-214.

Massumi, Brian. 2002. Parables for the virtual: Movement, affect, sensation. Durham, N.C.: Duke University Press.

Merlino, Mara L., Victoria Springer, Jan Seaman Kelly, and Derek Hammond. 2007. Meeting the challenges of the Daubert trilogy: Refining and redefining the reliability of forensic evidence. Tulsa Law Review 43: 417-446.

Mol, Annemarie. 2002. The body multiple: Ontology in medical practice. Durham, NC: Duke University Press.

Murphy, Sean V., and Anthony Atala. 2014. 3D bioprinting of tissues and organs. Nature Biotechnology 32 (8): 773-785.

Murphy, Thérèse. 1997. Feminism on flesh. Law and Critique 8 (1): 37-59.

Naffine, Ngaire. 2019. Criminal law and the man problem. Oxford: Bloomsbury Publishing.

Nakashima, Richard A. 1995. DNA evidence in criminal trials: A defense attorney's primer. Nebraska Law Review 74: 444-478.

Norrie, Alan. 2014. Crime, reason and history: A critical introduction to criminal law. Cambridge: Cambridge University Press.

Orlie, Melissa A. 2010. Impersonal matter. In New materialisms: Ontology, agency and politics, ed. Diana Coole and Samantha Frost, 116-138. Durham, N.C.: Duke University Press.

Phillips, Anne. 2015. The politics of the human. Cambridge: Cambridge University Press.

$R$ v. BM. 2018. In LLR 514, EWCA Crim 560.

$R v$. Bollom. 2003. In EWCA Crim 2846.

$R$ v. Dica. 2004. In EWCA Crim 1103, [2004] QB 1257.

$R$ v. Donovan. 1934. In 2 KB 498.

$R$ v. Janjua. 1999. In 1 CR App R 91.

$R$ v. Morris (Clarence Barrington). 1997. In EWCA Crim 2564.

Rahmani, Benyamin, Christopher McGregor, Guerard Byrne, and Gaetano Burriesci. 2019. A durable porcine pericardial surgical bioprosthetic heart valve: A proof of concept. Journal of Cardiovascular Translational Research 12: 331-337.

Ramachandran, Gowri. 2010. Assault and battery on property. Loyola of Los Angeles Law Review 44 (1): 253-276.

Rawls, John. 2009. A theory of justice. Cambridge, MA: Harvard University Press.

Razack, Sherene. 2002. Gendered racial violence and spatialised justice: The murder of Pamela George. In Race, space, and the law: Unmapping a white settler society, ed. Sherene Razack. Toronto: Between the Lines.

Razack, Sherene. 2008. Casting out: The eviction of muslims from western law and politics. Toronto: Toronto University Press.

Redmond, Caroline. 2018. 25 vintage murder scenes from Old New York.

Rodabough, Tillman. 2003. The evolution of the legal definition of death. In Handbook of death and dying: Volume one. The presence of death, ed. Clifton D. Bryant, 284-291. Thousand Oaks, CA: Sage.

Savulescu, Julian, Ruud ter Meulen, and Guy Kahane. 2011. Enhancing human capacities. Chichester: Blackwell.

Scott, Charles C. 1945. Medicolegal photography. Rocky Mountain Law Review 18: 173-239.

Scott, Charles C. 1946. X-ray pictures as evidence. Michigan Law Review 44 (5): 773-796.

Sharp, Lesley Alexandra. 2007. Bodies, commodities, and biotechnologies: Death, mourning, and scientific desire in the realm of human organ transfer. New York: Columbia University Press.

Smith, David Randolph. 1985. Legal recognition of neocortical death. Cornell Law Review 71: 850. 
Smolensky, Kirsten Rabe. 2006. Defining life from the perspective of death: An introduction to the forced symmetry approach. University of Chicago Legal Forum 1 (3): 41-85.

Spinoza, Baruch. 1992. Ethics: Treatise on the emendation of the intellect and selected letters. Trans. Samuel Shirley. Indianapolis, IN: Hackett Publishing.

Spivak, Gayatri. 1988. Can the subaltern speak? In Marxism and the interpretation of culture, ed. Cary Nelson and Lawrence Grossberg. London: MacMillan.

Standal, Øyvind F. 2011. Re-embodiment: Incorporation through embodied learning of wheelchair skills. Medical Health Care and Philosophy 14: 177-184.

Thakor, Nitish V. 2013. Translating the brain-machine interface. Science Translational Medicine 5 (210): 210ps17.

Verhoeven, T., P. Buteneers, J.R. Wiersema, J. Dambre, and P.J. Kindermans. 2015. Towards a symbiotic brain-computer interface: Exploring the application-decoder interaction. Journal of Neural Engineering 12 (6): 066027.

Wakefield, Edward Gibbon. 2010. The making of modern law, legal treatises, 1800-1926: The punishment of death in the metropolis. London: Gale.

Wilson, Robert Rawdon. 1995. Cyber (body) parts: Prosthetic consciousness. Body \& Society 1 (3-4): 239-259.

Zylinska, Joanna. 2002. 'The future....is monstrous': Prosthetics as ethics. In The cyborg experiments: The extensions of the body in the media age, ed. Joanna Zylinska, 214-236. London: Continuum.

Publisher's Note Springer Nature remains neutral with regard to jurisdictional claims in published maps and institutional affiliations. 